\title{
Emulation, indebtedness and income distribution: A monetary theory of production approach
}

\author{
Guglielmo Forges Davanzati and Andrea Pacella*,**
}

\begin{abstract}
The aim of this paper is to study the effect of emulation within a basic schema of the monetary theory of production (MTP). A theoretical model is presented, where workers set their target level of consumption based on the comparison with other workers taken as reference. It is shown that emulation can play a crucial role in increasing workers' propensity to indebtedness. As a result, profits increase and so does the price level, thus generating a decline of the real wage. Moreover, the existence of indebtedness can provide a further solution to the socalled "paradox of profits" within the MTP.

JEL classifications: D7I, EI2, E2I, J3I

Keywords: monetary circuit, emulation, indebtedness, profits, wages
\end{abstract}

\section{Introduction}

The European Central Bank reports that the rate of variation of negotiated wage rates, with respect to the previous year, declined from $6.65 \%$ in 1992 to $2.16 \%$ in 2007 and that the inflation rate grew from $\mathrm{I} .8 \%$ in 2000 to $3.5 \%$ at the beginning of 2008 . The IMF then reports that, in the case of the USA, there was a fall in real wages of about Io \% between the '7os and the ' $905,6 \%$ of which corresponds to the fall between the ' 8 os and the '9os. Hein and Truger (2007: 225) find that "moderate wage increases were accompanied by a decline

* University of Salento.

** We wish to thank Giuseppe Fontana, Riccardo Realfonzo, Mario Seccareccia and Gennaro Zezza for their helpful comments on a previous draft of the paper.

Correspondence Address:

Guglielmo Forges Davanzati, University of Salento, Facoltà di Scienze Sociali, Politiche e del Territorio, Dipartimento di Filosofia e Scienze Sociali, Via Stampacchia, 73Ioo Lecce, Italy, e-mail: g.forges@ sesia.unile.it.

Received oI July 2008, accepted o8 February 2009

(C) INTERVENTION 7 (I), 2010, 147-I65 
in the labour income share, both in the Euro area and in the USA « and that, in particular, the labour income share in the Euro area passed from about $62 \%$ in 1992 to about $57 \%$ in 2005 , while - in the USA - it started from over $63 \%$ to reach $62 \%$ in 2005. The European Central Bank also reports that entrepreneurial net income raised from 504,I34 million $€$ in 1999 to I,033,93I million $€$ in 2008. ${ }^{\mathrm{I}}$ Importantly, in the Eurozone, the consumer credit index - provided by the ECB - has grown from 7.6 in 2004 to 8.7 in 2008. Evidence also shows the increase of consumption of luxury goods due to the increase of the financial sphere (above all, of banks' profits at the beginning of 2000's). Palley (2007), in particular, shows that the rentier share rose dramatically in the period between the r970s and the I990s, and that it generated increasing income inequality and a decline in the growth rate. Power et al. (2003) also report that the rentier income share in the USA rose from about is $\%$ in the 1960 s to about $35 \%$ in the 1990 , and that it continued to rise from 1995 to 2000 , reaching about $45 \%$. These figures have been at the basis of a widespread debate on the causes of the increasing inequality of income distribution as well as on the role of consumer credit in contemporary capitalist economies, and this paper aims at providing some theoretical hints in order to interpret them from a heterodox point of view.

Conventional wisdom, in fact, supports the idea that increasing worker indebtedness is mainly caused by financial deregulation - which allows cheaper and easier access to consumer credit - and low interest rates. It is also maintained that it tends to produce positive social outcomes, since consumer credit growth is high when households are optimistic about their future income and, thus, consumer credit growth is positively related to future consumption (Maki 2000). In this view, financial innovations - such as the development of subprime mortgages - allow a relaxation of credit rationing, favouring the poor or those in minority communities, previously considered too risky by traditional lenders (Kiff/Mills 2007). ${ }^{2}$ Moreover, as suggested by Bertola and Koeninger (2007), among others, the reduction of financial constraints has a positive effect on investments in human capital.

By contrast, some heterodox economists - particularly within Marxian-Kaleckian theoretical approaches - have recently pointed out that indebtedness derives from low wages and from restrictive fiscal and monetary policies and that it is grafted onto

"a 'financial form of Keynesianism: it is an asset-based Keynesianism, a 'privatised Keynesianism, crucially dependent on the ability of the banking system to support or even produce bubbles« (Bellofiore/Halevi 2009: 3). ${ }^{3}$

I URL: http://sdw.ecb.europa.eu.

2 The mainstream view also provides a microeconomic approach to consumer credit, based on the idea that the credit contract is signed in conditions of asymmetric information. See Soman/Cheema (2002), Sullivan et al. (2000 and 200I) and Lawrence (2008), among others.

3 The effects of consumer credit on the business cycle has recently been explored by Tagkalakis (2007), among others, who remarks that private indebtedness contributes to reducing the intensity of the recessive phases and that this effect is in operation only in contexts where the banking system is accommodating. Moreover, if this is not the case, he finds that expansive fiscal policies are not effective (see also Bouveng 1966 and Slocum/Lee Mathews 1970). 
On the empirical ground, Seccareccia (2005) finds a positive relation between restrictive fiscal policy and household indebtedness. He argues that household indebtedness, in contexts where taxation increases and/or public expenditure decreases, serves the sole purpose of guaranteeing a constant level of consumption, thus not giving rise to an increase in consumption and therefore to a multiplier effect (i.e. what he names a ‘bad indebtedness). Following this line of thought, this paper aims to explore the theoretical nexus between indebtedness and money profits, supporting the view that indebtedness ultimately depends on emulative effects. Using the Monetary Theory of Production (hereafter MTP) as the theoretical framework, this paper addresses two questions: a) How does income distribution vary when indebtedness-driven emulative behaviours in consumption are in operation? b) Can the consideration of the existence of emulative behaviours in consumption help to solve the sparadox of profits « which arises in the MTP, i.e. the impossibility for firms to obtain a monetary surplus? It will be shown that indebtedness on the part of workers is an important condition for making money profits, both for industrial firms and for banks, and that it ultimately produces a less equal income distribution. ${ }^{4}$

The exposition is organized as follows. Section 2 presents the general theoretical framework, by superimposing the role of emulative behaviours onto the basic scheme of the MTP; in Section 3 a model is presented, designed to show that income inequality increases along with the level of indebtedness, thus generating a decline in real wages and the realization of a money surplus. Section 4 concludes.

\section{The theoretical framework: The monetary theory of production and the saradox of profits}

The Monetary Theory of Production (or circuit approach) is based on the idea that contemporary economies are credit economies, as stated by Keynes above all in $A$ Treatise on Money of 1930 (see Arena/Salvadori 2004, Fontana/Realfonzo 2005). It is ultimately based on the assumption that the process of creation of purchasing power is endogenous and demand-driven, depending on firms' demand for credit, i.e. for so-called initial finance (see Realfonzo 2003). In this context, banks are not pure financial intermediaries and - by contrast with the mainstream view - >loans make deposits،. The monetary circuit is supposed

4 In a similar vein Lown (2005) who has recently argued "at the same time that bankruptcy rates are rising, credit card issuers have increased their profits by aggressively expanding their marketing and extending credit to marginal borrowers they would not have considered only a decade before. Despite the higher risks of default and bankruptcy, high interest rates, over the limit fees, and late penalties paid by marginal borrowers result in substantial profits. This expansion of consumer credit to marginal borrowers has been referred to as the democratization of credit whereby everyone, regardless of ability to repay, has the right to borrow money, even if the interest rates are extortionate. While the decade of the gos is well known for the booming stock market, for most Americans it was the decade of debt« (Lown 2005: 402, italics added). 
to develop in sequential steps which involve three macro-agents: banks, firms and workers. Credit is demanded when firms put their production plans into operation, and the amount of initial finance equals the money wage bill firms have negotiated with workers. At the end of the circuit, firms reimburse banks their debts. The reimbursement of debt is made possible via money revenues firms can collect in the market for goods and/or via money they collect by selling securities in the financial market (Graziani 2003). Since at best firms can only recoup the total amount of the initial finance, there is a problem of how they can make sufficient revenues to not only pay interest, but make a profit. The lack of realization of a monetary surplus can be seen as a theoretical problem if one rejects the conviction supported, among others, by Graziani (2003) - that a snormal level of indebtedness on the part of firms toward the banking system is a key feature of contemporary capitalist economies. Different solutions have been put forward (see Dupont/Reus 1989, Parguez 2004). Some authors maintain that profits can be obtained only in real terms (see Bellofiore/Realfonzo 1997). Others introduce variants of the standard structure using multi-sectorial models (see Parguez 1980, Seccareccia 2003), including profits in the same wage bill (see Rossi 2002) or additional demands expressed by the State and/or by the external sector or by the banks themselves (see De Vroy 1988, Renaud 2000). Following this line of thought, Parguez (2007) remarks that the reproduction of the capitalist system - as represented in the MTP - can be guaranteed above all via expansionary fiscal policies. ${ }^{5} \mathrm{Nell}$ (2002) points out that a basic if neglected step in monetary theory is to show that a given amount of money will enable all transactions to take place in money, in contexts where the money advanced equals the current costs. He proposes to solve the problem by considering the interdependences existing between different sectors and the different sequences of transaction among sectors, also by considering that financing involves a sequential process, within a Kaleckian theoretical framework (see also Renaud 2000). Messori and Zazzaro (2005) show that monetary profits can be generated by the bankruptcy of the less efficient firms, and Zazzaro (2003: 234) emphasises that this solution leads to abandoning "any concept of subjective and/or objective equilibrium [...] in favour of a systemic concept of order«. Zezza (2004) argues that - since in the MTP theoretical framework banks aim at obtaining interest payments in order to pay for their costs of production (namely, their employees' wages) plus profits to distribute to bank owners, firms' money profits ultimately derive from undistributed profits obtained by the banking sector as well as from wages of workers in the banking sector. Rochon (2005: I25) finds that monetary profits may be made in cases where the bank is divided between short term and long term contracts. Chapman and Keen (2006) show

5 The author argues that expansionary fiscal policy can be regarded as an sanchor of profit expectations. He stresses that expansive fiscal policy allows employment to increase thanks to the additional flow of money that the State produces. In short, the higher the deficit spending the higher the employment in the public sector and, since firms' expectations of profits rise, the higher the additional employment in the private sector. See also Bliek and Parguez (2006 and 2007) who also focus - within a schema of the MTP - on the role of consumer spending in increasing total demand and money profits. 
that aggregate money profits can arise in a dynamic context where a continuous time function is considered in overlapping circuits. Febrero (2008) maintains that firms as a whole can obtain money profits - within one single circuit - by means of long-term debt with the banking system. By inserting Veblenian elements into the basic schema of the MTP, Forges Davanzati and Realfonzo (2009) provide a theoretical model where the economy is considered as being formed by two sectors: one producing wage goods, the other producing luxury goods. Financial rents have a double nature. They are both a cost for firms, in the form of the interest bill, and an item of demand (for luxury goods). Consumption on the part of the leisure class increases the demand, and thus profits, of firms operating in the sector producing luxury goods.

However circuitists have devoted little attention to the role of consumer credit, although evidence shows that it has become a major feature of contemporary capitalist economies. ${ }^{6}$ Within this theoretical framework Pacella (2008) has recently shown that positive variations of workers' propensity to indebtness can have a positive effect on employment thanks to additional expansion of consumption. ${ }^{7}$ Otherwise, as will be shown, on purely theoretical grounds, indebtedness on the part of workers can allow firms to obtain aggregate money profits, thus providing a further possible solution to the sparadox of profits، It is worth noting that the paradox of profits is not something which pertains to the logical structure of the MTP and, hence, it should not be conceived as a pure logical puzzle. On the contrary, it focuses on a key problem of the capitalist system, namely the problem of the realization of a monetary surplus (see Bellofiore et al. 2000). One can argue that depending on historical and social conditions - capitalism solves the problem in different ways (i.e. increasing public expenditure, promoting export), and that indebtedness on the part of workers - not being a mere soutside factor used here as an ad hoc assumption - is, as a matter of fact, a social device functional to the reproduction of the system. In this sense, the MTP approach provides an sopen model, where the closure of the circuit depends on soutside factors ‘ which are historically, institutionally and socially determined, as well as empirically/factually significant. It should be added that - by its very nature - the problem of the realization of a monetary surplus is a macroeconomic problem. The mainstream view is rejected here, i.e. the idea that household indebtedness ultimately depends on low interest rates and on the increasing quality of financial products, while it is maintained that workers tend to get into debt when wages are low. Moreover, it is suggested that wages are perceived as slow when workers compare their standard of living with that of richer individuals. Ac-

6 Cynamon and Fazzari (2008), among others, provide massive evidence on the role of consumer credit in the expansion of the US economy during the last decade, within a theoretical framework where it is assumed that financial preferences evolve as social norms, interacting with both cultural trends and institutional changes.

7 Within the mainstream view, the links between consumer credit and aggregate demand have been explored, in particular, by Jappelli and Pagano (1989 and 1994) who find a low reactivity of consumption with respect to indebtness (see also Ludvigson 1999). For a study of the dynamics of consumption composition in relation to variations in private indebtness see in particular Messinis et al. (2002). 
cordingly, workers' propensity to become indebted is seen here as the result of emulative behaviours, which ultimately determine their target level of consumption. ${ }^{8}$

In this theoretical context, emulation is strictly connected with class affiliation. ${ }^{9}$ Individuals do not choose in an institutional vacuum but compare their consumption with that of others, i.e. the consumption of individuals belonging to certain reference groups. ${ }^{\text {IO }}$ Post Keynesian scholars stress the role of wage relativities in industrial relations. ${ }^{\text {II }}$ In her seminal contribution, Joan Robinson (1962: 70) points out that "the cause of movements in moneywages is bound up with the competition of different groups of workers to maintain or improve their relative position «. Wiles (1973: 379) observes that »the communication revolution [...] making everyone instantly aware of everything, has sharply increased the amount of envy and imitation in the world «. Rowthorn (1977) considers that wages are a function of the level of unemployment - due to the sindustrial reserve army effect - and of the consumption on the part of high-paid workers, so that if the general wage level is expected to rise, each group of workers will demand wage increases so as to preserve their relative position in the wage hierarchy. ${ }^{\mathrm{I2}}$ Lavoie (1992: 379) remarks that the "core of a Post-Keynesian explanation of price and wage inflation [is] based on the notion of equity « and that equity, in turn, is strictly linked to the "normative pressures of relative fair wages and the need to preserve one's status within the pecking order of labour hierarchy « ${ }^{\mathrm{I3}}$.

8 Cf. Pacella (2008) in which worker indebtness is proportionate to the reduction of workers' bargaining power in the labour market.

9 In a similar vein see Hayakawa and Venieris (1977) and Lee Mathews and Slocum (1969). The basic mainstream approach to consumer behaviour, considering that preferences are exogenous, does not take emulative effects into consideration. By contrast, insofar as emulation implies endogenous preferences, it does not rely on methodological individualism. The conviction that income comparison is a major factor for understanding individual decisions is shared by many sheterodox s scholars, belonging to different strands: post-Keynesians, Institutionalists, economists dealing with Neuroeconomics, Experimental Economics, Behavioural Economics, and Ethical Economics. For a general survey see, among others, Schmid (2004). On a historical reconstruction of theories of emulation see Hayakawa (1999).

IO In a similar vein, Bowles and Park (2005) reach the conclusion that working hours go up as the inequality of income distribution increases. This may occur because the desire to emulate the standard of consumption of the rich influences workers' allocation of time between labour and leisure (see also Corneo/Jeanne 1999).

II In the General Theory, Keynes (1936: I4) emphasises that "any individual or group of individuals, who consent to a reduction of money-wage relatively to others, will suffer a relative reduction in real wages, which is a sufficient justification for them to resist it«.

I2 Wage relativities are sometimes used to explain the determination of the 'fair wage, in the conviction that the notions of equity and justice are an important part of non-orthodox economics in comparison with the mainstream view (Lavoie 1992: 379).

I3 He adds that to "follow the opinion of the majority « is one of the basic strategies in order to face uncertainty in a Keynesian world. Moreover, imitative behaviour constitutes a helpful guide in decisions and tends to become a norm: these norms, in turn, represent ,focal points since they are generated by the opinions of the most powerful and respected groups. See also Setterfield (2007). 
Figure I describes the functioning of the monetary circuit in a context where banks also provide consumer credit.

Figure I: The monetary circuit with consumer credit

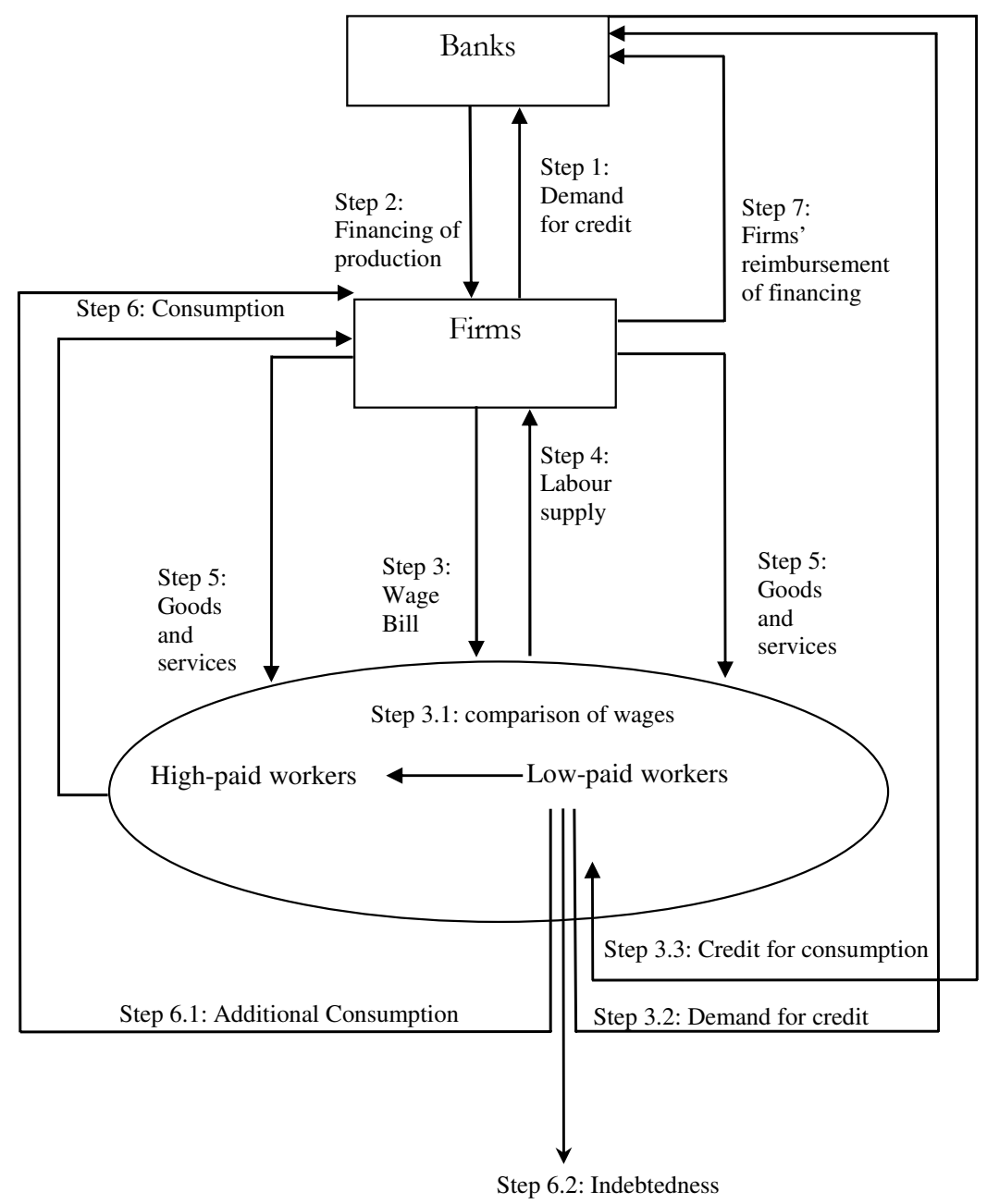

Assuming that banks supply purchasing power when someone asks for it, and by considering that possible exchanges within the firm sector give rise to a zero-sum game (see Graziani 2003), the demand for credit equals the money wage bill (so-called initial finances). This is the beginning of the circuit (steps I and 2). Firms as a whole use credit in order to pay 
workers (step 3), and workers supply labour services (step 4). If, for the sake of simplicity, it is assumed that the propensity to consume equals I, no savings are available to the banking system or to the financial markets. Therefore, as financial markets are not in operation, the entire money wage bill comes back to firms once workers acquire consumption goods and services (steps 5 and 6). As stated below, if two groups of workers exist, and low paid workers emulate high paid workers via consumer credit, additional purchasing power flows have to be considered. ${ }^{14}$ Banks finance low-paid workers (steps 3.2 and 3.3), thus giving rise to additional consumption (step 6.I) to the benefit of firms, and indebtedness on the part of workers (step 6.2). Finally, firms reimburse banks their debts in step 7.

\section{Emulation raises profits: Workers' indebtedness and inequality}

The role of emulation in affecting the path of income distribution within the theoretical framework of the MTP - as described in the previous section - is now captured by a simple macroeconomic model, based on the following assumptions.

I) The economy is formed by two sectors, where two consumption goods (I and 2) are produced. Type-I firms are assumed to provide good jobs, and to pay their workers higher wages than type-2 firms. ${ }^{15}$ Firms fix prices under the mark-up rule, and the money interest rate - being a cost of production - enters the price equation (see Docherty 2005), i.e. $p=(w / \pi)(1+r)(1+i)$, where $p$ is the unitary price, $w$ is the unitary money wage, $\pi$ is labour productivity, $r$ the normal rate of profits and $i$ the money rate of interest. ${ }^{16}$

2) At the beginning of the monetary circuit, the following conditions hold: $p_{1}>p_{2},{ }^{17}$ with $w_{1}>w_{2}$ and $\pi_{1}=\pi_{2},{ }^{18} i_{1}=i_{2}, r_{1}=r_{2}$. Workers in Sector 2 - being low-paid - emulate

I4 Note while type-I workers have a propensity to consume equal to I, type-2 workers have a propensity to consume higher than I.

I5 Fairris and Jonasson (2008: 98) point out that while neoclassical economic models of perfectly competitive labour markets explain pay differences across workers on the grounds of the differences in human capital and of the quality of working conditions (the so-called theory of compensating differentials), heterodox economics - and, particularly, institutional labour economics - emphasises that "pay may be positively related to firm size, the cost of labour turnover, the difficulty of monitoring labour effort, or the need to attract a more talented applicant pool«.

I6 The idea that the interest rate, being a cost of production, enters the price function is also supported - within a Sraffian theoretical framework - by Pivetti (I99I). It is worth noting that - in this scheme - the interest rate is a stax on profits. Moreover, following the Marxian argument, one can argue that if the interest rate significantly increases, capitalists may find it convenient to allocate resources in the money and/or financial market.

I7 This condition derives from the fact that wages paid by type-I firms are higher than wages paid by type-2 firms.

I8 The assumption of equal labour productivities can be justified with the argument that while productivity of high-paid workers, usually employed in big firms, mainly depends on the stock of (hu- 
workers in Sector I, according to the Keynesian effect described above, and also considering that a sense of fairness may encourage low-paid workers to react to the wage differentials not justified by labour productivity differentials. They are unable to reach this goal by obtaining higher money wages via wage bargaining and, therefore, they contract debts with the banking system in order to obtain a level of income at least equal of that of workers in Sector 2. ${ }^{19}$ Workers spend a ratio of their current wage to repay debt. The banking system is assumed to be accommodating, both with respect to the demand for finance on the part of firms and to consumer credit. For the sake of simplicity, it is assumed that consumers demand an equal amount of goods I and 2, and that the money interest rate is equal both on firms' and workers' demand for credit. The unitary money wage is a given, depending on the relative bargaining powers of workers and firms and the level of employment is settled based on the degree of capital utilization (cf. Lavoie 1992: ch. 5).

3) It is assumed that current investments have been financed in the previous circuit. ${ }^{20}$

The employment functions in the two sectors are:

$$
\begin{aligned}
& N_{1}\left(\begin{array}{c}
K_{1} ; d_{1} \\
++
\end{array}\right)=d_{1} K_{1} \\
& N_{2}\left(\begin{array}{c}
K_{2} ; d_{2} \\
+
\end{array}\right)=d_{2} K_{2}
\end{aligned}
$$

Where $N_{1}$ and $N_{2}$ are respectively the number of workers employed in Sector I and Sector 2, while $K$ is the amount of capital and $0 \leq d_{1} \leq 1$ and $0 \leq d_{2} \leq 1$ are respectively the rate of utilization of capital in Sector I and in Sector 2. For the sake of simplicity a constant rate of capital utilization is assumed here. ${ }^{21}$ The two sectors are not integrated and the distribution of employment among the two sectors is a given, depending on the specialization of the economy. Given $w_{1}$ and $w_{2}$, the wage bill paid in both the sectors becomes:

man and physical) capital they can use, low-paid workers, usually employed in small firms with high job insecurity, are forced to provide firms with high labour intensity in order to increase the probability of the renewal of their contracts. See Ramaswamy/Rowthorn (I99I).

I9 The rationale for this assumption can be found in different factors, above all the consideration that usually low-paid workers enter temporary labour contracts with high job insecurity. Therefore, they are likely to be more interested in the renewal of their contracts than in high wages. Otherwise, labour ,flexibility acts as a discipline device, thus reducing union bargaining power. Moreover, even if an equal bargaining power of high-paid and low-paid workers is assumed, the relative incomes do not vary and, as a result, emulation still occurs, and it still occurs to the same degree. It could be added that - in a dynamic framework - insofar as low-paid workers systematically enjoy a lower bargaining power, the aspiration gap tends to become higher and higher and, as a result, low-paid workers' indebtedness would tend to grow over time.

20 This assumption will be discussed below.

2I This assumption will be discussed below. 


$$
\begin{aligned}
& w_{1} N_{1}\left(\begin{array}{c}
K_{1} ; d_{1} \\
++
\end{array}\right)=w_{1} d_{1} K_{1} \\
& w_{2} N_{2}\left(\begin{array}{c}
K_{2} ; d_{2} \\
+
\end{array}\right)=w_{2} d_{2} K_{2}
\end{aligned}
$$

The Keynesian emulative effect is captured by the following equation:

$$
\begin{aligned}
& w_{1}^{D}\left(\begin{array}{c}
w_{1} \\
+
\end{array}\right)=w_{1} \\
& w_{2}^{D}\left(\begin{array}{c}
w_{1} ; \alpha \\
+
\end{array}\right)=\alpha w_{1}
\end{aligned}
$$

Equation 5 shows the desired wage by the high-paid workers which is assumed to be exactly equal to the wage earned in Sector I. On the other hand low-paid workers desire a level of wage higher than what they can obtain in Sector 2. Specifically, low-paid workers aim at gaining $\alpha w_{1}>w_{2}$ of the wage earned in Sector Id in Sector I. $\alpha$ is here named as degree of emulation exogenously given. While the wage bill desired in Sector I is exactly equal to its effective level the wage bill desired in Sector 2 is given by the following function

$$
w_{2}^{D}\left(\begin{array}{c}
w_{1} ; \alpha \\
++
\end{array}\right) N_{2}\left(\begin{array}{c}
K_{2} ; d_{2} \\
++_{+}
\end{array}\right)=\alpha w_{1} d_{2} K_{2}
$$

On the basis of equations (7) and (4) we can find the amount of financial need of type-2 workers which shows the amount of credit demanded by the same group and supplied by banks.

$$
F W_{2}=w_{2}^{D}\left(\begin{array}{c}
w_{2} ; \alpha \\
+
\end{array}\right) N_{2}\left(\begin{array}{c}
K_{2} ; d_{2} \\
+
\end{array}\right)-w_{2} N_{2}\left(\begin{array}{c}
K_{2} ; d_{2} \\
+
\end{array}\right)=d_{2} K_{2}\left(\alpha w_{1}-w_{2}\right)
$$

Given (8) the debt of type-2 workers will be given by the financial need plus interest:

$$
D_{2}=F W_{2}(1+i)=d_{2} K_{2}\left(\alpha w_{1}-w_{2}\right)(1+i)
$$

where $i$ is the average rate of interest on the total amount of workers' financing. ${ }^{22}$ Let us assume a reimbursement plan of the debt with constant repayments. Given $n$ periods the debt reimbursed in each period will be:

$$
R D_{2}=\frac{D_{2}}{n}=\frac{F W_{2}(1+i)}{n}=\frac{d_{2} K_{2}\left(\alpha w_{1}-w_{2}\right)(1+i)}{n}
$$

22 For the sake of simplicity the average rate of interest on the total amount of workers' financing is assumed to be equal to the interest rate paid by firms on the wage bill anticipated by banks. 
We can now find the ratio of the wage bill that type-2 workers will set aside so as to repay their debt. ${ }^{23}$ We have:

$$
R D_{2}=\gamma w_{2} d_{2} K_{2}
$$

Where

$$
\gamma=\frac{R D_{2}}{w_{2} d_{2} K_{2}}=\frac{\left(\alpha w_{1}-w_{2}\right)(1+i)}{w_{2} d_{2} K_{2}}
$$

Aggregate net money profits are:

$$
\Pi=w_{1} N_{1}+w_{2} N_{2}+F W_{2}-w_{1} N_{1}-w_{2} N_{2}-R D_{2}-i F_{I}=F W_{2}-R D_{2}-i F_{I}=F W_{2}\left[1-\frac{1+i}{n}\right]-i F_{I}
$$

Where $F_{1}$ is the total amount of financing supplied to firms.

$$
\Pi=\frac{1}{n} d_{2} K_{2}\left(\alpha w_{1}-w_{2}\right)(n-1-i)-i \sum_{j=1}^{2} w_{j} d_{j} K_{j}
$$

Equations I 3 and I4 establish that aggregate money net profits increase I) in consumer credit and, hence, in the degree of emulation among workers, 2) in the number of periods (n) where workers must reimburse their debt, and decrease in the money interest rate. ${ }^{24}$ Note also that the higher the employment level in Sector 2, the higher the aggregate money profits. This is because only workers employed in Sector 2 enter consumer credit and, hence, only these workers provide firms with an excess of liquidity compared to their wage. The rationale for conclusion $\mathrm{I}$ ) is that banks' financing of consumption constitutes an additional input of purchasing power into the monetary circuit, while the rationale for conclusion 2 ) is that as $\mathrm{n}$ increases, the available gross income also increases in the current period, thus giving rise to an increase in current expenditures. Accordingly, the sparadox of profits` can be solved by considering that banks also finance workers by means of consumer credit.

The formal conditions for $\pi>0$ are the following:

$$
\Pi>0 \Rightarrow F W_{2}>\frac{n i}{n-1-i} \sum_{j=1}^{2} w_{j} d_{j} K_{j}
$$

23 Workers' propensity to set aside part of their income to repay debt is likely to depend on institutional factors (such as the prevailing customs underlying bank-consumer contracts) as well as on workers' expectations on their future wages. Specifically, if workers expect an increase of future wages they will tend to consume more in the present period. Moreover, it is likely to depend also on the interest rate. In particular, a high interest rate may discourage the demand for consumer credit and, as a result, reduce demand and hence profits. The inverse relation between the rate of money interest and money profits is thus confirmed not only because high interest rates are directly a cost for firms, but also because high interest rates are indirectly associated with low profits via low workers' indebtedness and low aggregate demand. For the sake of simplicity, these effects are not explored here.

24 This latter conclusion holds under the condition that the demand for money on the part of firms is rigid enough, so that the increase in the money interest rate determines a consequent increase in $i F_{1}$. 


$$
\begin{gathered}
\Pi>0 \Rightarrow i<\frac{F W_{2}(n-1)}{F W_{2}+n F_{I}} \Rightarrow i<\frac{d_{2} K_{2}\left(\alpha w_{1}-w_{2}\right)(n-1)}{d_{2} K_{2}\left(\alpha w_{1}-w_{2}\right)+n \sum_{j=1}^{2} w_{j} d_{j} K_{j}} \\
\Pi>0 \Rightarrow n>\frac{F W_{2}(1+i)}{F W_{2}-i F_{I}} \Rightarrow n>\frac{d_{2} K_{2}\left(\alpha w_{1}-w_{2}\right)(1+i)}{d_{2} K_{2}\left(\alpha w_{1}-w_{2}\right)-i \sum_{j=1}^{2} w_{j} d_{j} K_{j}}
\end{gathered}
$$

Equation I5a establishes that - for any values of $n$ - the interest bill on the part of firms must be lower than workers' indebtedness. Equation I5b establishes that as $n$ increases, since this implies a higher gross disposable income in the present period, the money interest rate must fall in order to guarantee aggregate money profits higher than zero. By contrast, equation $15 \mathrm{C}$ states that as the interest rate on consumer credit increases, the number of periods in which workers repay their debt must increase in order to guarantee positive monetary aggregate profits.

Let us now analyse the relation between consumer credit and the price level. Since, by assumption, firms fix prices based on the mark-up rule, and including interest, prices in the two sectors are:

$$
\begin{aligned}
& p_{1}=\frac{w_{1}}{\pi}\left(1+r_{1}\right)(1+i) \\
& p_{2}=\frac{w_{2}}{\pi}\left(1+r_{2}\right)(1+i)
\end{aligned}
$$

where $w_{1}>w_{2}$ and, hence, since labour productivity, the rate of profits and the interest rate are equal in both sectors, $p_{1}>p_{2}$. Moreover, insofar as workers distribute their consumption in equal parts between both sectors, profits in Sector I equal $1 / 2$ of total profits. Hence:

$$
\begin{aligned}
& r_{1}=\frac{\frac{1}{2} \Pi}{w_{1} N_{1}}=\frac{d_{2} K_{2}\left(\alpha w_{1}-w_{2}\right)(n-1-i)-n i \sum_{j=1}^{2} w_{j} d_{j} K_{j}}{2 n w_{1} d_{1} K_{1}} \\
& r_{2}=\frac{\frac{1}{2} \Pi}{w_{2} N_{2}}=\frac{d_{2} K_{2}\left(\alpha w_{1}-w_{2}\right)(n-1-i)-n i \sum_{j=1}^{2} w_{j} d_{j} K_{j}}{2 n w_{2} d_{2} K_{2}}
\end{aligned}
$$

Note that $d$ can be conceived as both a constant rate of capital utilization - depending on purely technical variables, as assumed here for simplicity's sake - and a ‘behavioural coefficient, relating above all to firms' expectations on aggregate demand. Within the Post Keynesian theoretical framework, three main views on this issue can be traced. In his seminal contribution, Sylos Labini (I97I) argues that firms use their capital stock as a device in order to prevent the entry of competitors in oligopolistic markets. Steindl (I952) stresses that 
- as a rule - firms do not exploit the whole capital they have, due to the fact that maintaining capital underutilization can solve the problem of rapidly increasing production when demand increases, in contexts of high and fundamental uncertainty. Lavoie (I992: I25) maintains that a firm's tendency to underutilize capital depends on purely technical factors, namely the indivisibility of plants.

For the sake of the argument presented here, by relaxing the initial assumption, one can regard $d$ as a variable, depending on expected demand. In this context, the key question regards the relation between $d_{1}$ and $d_{2}$, since - as resulting from equations (I8) and (I9) - type-I profits increase as $d_{2}$ increases, for every variation of $d_{1}$. At the same time, if $d_{2}$ increases so does the price of type-I firms $\left(p_{1}\right)$, since $p_{1}$ includes the rate of profits, which, in turn, is positively affected by the increase in capital utilization on the part of type-2 firms. This conclusion states that the improvement of expectations on the part of type- 2 firms, by increasing the rate of profits of type-I firms, generates a reduction of real wages. This occurs because - in this model - monetary profits can result only insofar as an influx of purchasing power external to firms as a whole is in operation.

By inserting I8 and I9 into the price equations, one obtains:

$$
\begin{aligned}
& p_{1}=\frac{w_{1}}{\pi}\left(1+\frac{\left.d_{2} K_{2}\left(\alpha w_{1}-w_{2}\right)(n-1-i)-n i \sum_{j=1}^{2} w_{j} d_{j} K_{j}\right)}{2 n w_{1} d_{1} K_{1}}\right)(1+i) \\
& p_{2}=\frac{w_{2}}{\pi}\left(1+\frac{d_{2} K_{2}\left(\alpha w_{1}-w_{2}\right)(n-1-i)-n i \sum_{j=1}^{2} w_{j} d_{j} K_{j}}{2 n w_{2} d_{2} K_{2}}\right)(1+i)
\end{aligned}
$$

And the average prices are:

$$
\frac{1}{2} \sum_{j=1}^{2} p_{j}=\frac{1+i}{2 \pi}\left[w_{1}+w_{2}+\left(\frac{w_{1}}{w_{1} d_{1} K_{1}}+\frac{w_{2}}{w_{2} d_{2} K_{2}}\right)\left(\frac{d_{2} K_{2}\left(\alpha w_{1}-w_{2}\right)(n-1-i)-n i \sum_{j=1}^{2} w_{j} d_{j} K_{j}}{2 n}\right)\right] \text { (22) }
$$

Equation 22 establishes that worker debt increases the price level, so that consumer credit causes inflationary pressures, and the greater the propensity to emulate, the wider the aspiration gap, and the higher the inflation.

On the basis of equation 22, the unitary real wages in the two sectors are:

$$
\frac{w_{1}}{\frac{1}{2} \sum_{j=1}^{2} p_{j}}=\frac{1}{(1+i)} \frac{2 \pi w_{1}}{w_{1}+w_{2}+\left(\frac{w_{1}}{w_{1} d_{1} K_{1}}+\frac{w_{2}}{w_{2} d_{2} K_{2}}\right)\left(\frac{d_{2} K_{2}\left(\alpha w_{1}-w_{2}\right)(n-1-i)-n i \sum_{j=1}^{2} w_{j} d_{j} K_{j}}{2 n}\right)}
$$




$$
\frac{w_{2}}{\frac{1}{2} \sum_{j=1}^{2} p_{j}}=\frac{1}{(1+i)} \frac{2 \pi w_{2}}{w_{1}+w_{2}+\left(\frac{w_{1}}{w_{1} d_{1} K_{1}}+\frac{w_{2}}{w_{2} d_{2} K_{2}}\right)\left(\frac{d_{2} K_{2}\left(\alpha w_{1}-w_{2}\right)(n-1-i)-n i \sum_{j=1}^{2} w_{j} d_{j} K_{j}}{2 n}\right)}
$$

Equations 23 and 24 establish that the higher the worker indebtedness, the lower the unitary real wage. This occurs because the increase in consumer credit determines an increase in profits and, hence, for a given value of capital, an increase in the average rate of profits. As a result, prices increase and, since the unitary money wage is a given, the average real wage declines. Hence, the more workers tend to become indebted - which, in turn, depends on their tendency to emulate - the more real wages tend to decline. Note that emulation on the part of type-I workers generates negative externalities at the expense of type- 2 workers, insofar as indebtedness produces a decline in real wages for workers as a whole. Consumer credit is, at the same time, the cause and effect of a >bad income distribution. Moreover, real wages also decline as the interest rate grows. This is because the increase in the interest rate produces an increase in prices and, hence, a reduction of $w / p .^{26,27}$

When a sector producing investment goods is explicitly considered, the following causal links hold. Since capital goods are produced to be sold to the sector producing wage goods, the expansion of this sector can occur only in the case firms producing consumption goods plan an expansion of the future output. If this is the case, in the current circuit, banks' financing of the production of capital goods implies that more workers are employed. For a given unitary money wage, total demand increases, and so do short-run profits of firms producing consumption goods. In the event workers employed in the sector producing capital goods are low paid workers, total demand increases not only for the increase in $N$, but also for the increase of indebtedness. In any case, firms producing consumption goods react by increasing prices, so that the increase of investments produce further inflationary pressures. This result is consistent with the conclusions reached in most MTP models, where - as emphasised, in particular, by Graziani (2003: 7I) - in a context where firms can autonomously decide to produce consumption goods or investment goods, this latter choice - by generating a decline of the supply of consumption goods - produces forced saving. ${ }^{28}$ However,

26 Note that a) the increase in prices reduces the real interest bill at the expense of the banking system. A possible reaction is the increase in the monetary interest rate, thus giving rise - in a dynamic context - to further inflationary pressure deriving from feedback effects involving interest-price dynamics; b) the decline of the average real wage is not stopped by an endogenous mechanism, even if the unitary real wage falls below a given level of subsistence wage. If this is the case, social conflict is likely to occur.

27 Contrary to Bertola/Koeniger (2007) the unequal income distribution here is generated within an accommodating banking system (in a similar vein see Brady 2007). The authors instead point out that a non accommodating banking system produces an unequal income distribution because of the reduction in debtors' available income.

28 In Graziani's model, capital goods are acquired by firms producing consumption goods by using their profits. This implies that »investment finds its final finance in savings" (Graziani 2003: 7I). 
in a long-run perspective, the increase of production of capital goods can produce increases in output and deflationary pressures, if the improvement of the quality of capital goods positively affects labour productivity.

Note also that interest payments are not only costs of production for firms, but also income accruing to wealthy households who own financial assets, so that these payments can be used to add to aggregate demand. The additional flow of money spent by rentiers or bankers does not invalidate our previous conclusions. At the end of the circuit, in fact bankers are in a position to spend their profits, partly deriving from the reimbursement of the financing by firms and partly deriving from the reimbursement of workers' indebtedness. Hein (2008: 3 and ch. 17) observes that the interest income (partly or wholly) may be spent in order to acquire consumption goods in a theoretical context where money supply is endogenous and the key variable for determining the amount of financial rents is the money interest rate set by the central bank. The expenditure on the part of bankers increases aggregate demand, thus amplifying the vicious circle described above, if capacity utilisation is taken to be given and constant: The increase of demand causes an increase in the rate of profits and, thus, of the price level, so that high financial rents are associated with low levels of real wages (Docherty 2005: 215). Note also that since, in this theoretical framework, employment is settled by firms under a given technological setting, the increase in demand does not affect it. Moreover, since financial rents are normally used to acquire luxury goods, and luxury goods are normally produced with low capital/labour ratio, high financial rents - in a long-run perspective - can significantly modify the specialization of the economy: In particular, it can push firms to use labour-intensive techniques (see Forges Davanzati 2007). ${ }^{29}$

The model suggests in conclusion that the distributive conflict is in operation on three different grounds. First, high bank profits, driven by high interest rates, reduce profits, via the increase in the financial costs for firms, thus giving rise to an inverse relation between the interest rate and the rate of profit (i.e. 'financialı vs. sindustrial circulation`). Second, industrial profits depend on low wages and, in the scheme proposed here, by workers' indebtedness, which in turn depends on the degree of emulation and on the degree of segmentation of the labour market. The rate of profit is hence inversely related to the average real wage because we have assumed a constant rate of capacity utilisation. Third, high interest rates, insofar as they determine high price levels, reduce the average real wage, so that the interest rate is inversely related to the rate of wages.

29 It could be added that - particularly in the US during the I990s - the growth of consumption had also to do with the growth of consumption of luxury goods and that the rentiers obtained their gains in the stock market. Moreover, as shown by Zezza (2008), a further source of income, for rich household, were the realised capital gains deriving from the acceleration in home prices. 


\section{Concluding remarks}

This paper dealt with two main questions. Firstly, the so-called paradox of profits which arises within the MTP is addressed, by stressing that worker indebtedness can guarantee the making of money profits for firms as a whole. Worker indebtedness, in turn, has been conceived here as being dependent on emulation, and, particularly, on the relative wage effect described by Keynes in the General Theory. Secondly, it has been shown that consumer credit is caused by and determines unequal income distribution. The rationale for this conclusion is that as debt increases, so does the rate of profits, and so does the price level. As a result, for a given unitary money wage, the higher the workers' debt, the lower the real wages.

\section{References}

Arena, R., Salvadori, N. (eds.) (2004): Money Credit and the Role of the State, Essays in Honour of Augusto Graziani, Aldershot: Ashgate Publishing Company.

Bellofiore, R., Forges Davanzati, G., Realfonzo, R. (2000): Marx inside the circuit. Discipline device, wage bargaining and unemployment in a sequential monetary economy, in: Review of Political Economy, I2(I), 403 - 4I7.

Bellofiore, R., Halevi, J. (2009): Deconstructing labor, What is snew in contemporary capitalism and economic policies: A Marxian-Kaleckian perspective, mimeo.

Bellofiore, R., Realfonzo, R. (1997): Finance and the labour theory of value, in: International Journal of Political Economy, 27, 97 - II8.

Bertola, G., Koeniger, W. (2007): Consumption smoothing and income redistribution, in: European Economic Review, 5I, 194I - I958.

Bliek, J.G., Parguez, A. (2006): Le pleinemploy ou le chaous, Paris: Economica.

Bliek, J.G., Parguez, A. (2007): Full employment: Can it be a key policy objective for Europe?, in: International Journal of Political Economy, 36(3), 24-46.

Bouveng, C.J. (1966): Some long term economic aspects, in: The Swedish Journal of Economics, 68(4), 234-26o.

Bowles, S., Park, Y. (2005): Emulation, inequality and work hours: Was Thorstein Veblen right?, in: The Economic Journal, $\mathrm{II} 5,397$ - 412.

Brady, R.R. (2007): Structural breaks and consumer credit: Is consumption smoothing finally a reality?, in: Journal of Macroeconomics, doi: I0.IoI6/j.jmacro.2007.04.004.

Chapman, B., Keen, S. (2006): Hic rodus, hic salta! Profits in a dynamic model of the monetary theory of production, in: Storia del Pensiero Economico, 2, I37 - I54.

Corneo, G., Jeanne, O. (1999): Pecuniarity emulation, inequality and growth, in: European Economic Review, 43, 1665- I678.

Cynamon, B.Z., Fazzari, S.M. (2008): Household debt in the consumer age: Source of growthrisk of collapse, in: Capitalism and Society, 3(2), Article 4.

De Vroy, M. (1988): Il circuito della moneta: Due interpretazioni, in: Messori, M. (ed.), Moneta e produzione, Torino: Einaudi, 215-245.

Docherty, P. (2005): Money and Employment, Cheltenham: Elgar. 
Dupont, F., Reus, E. (1989): Le profit macroéconomique monétaire, in: Economie Appliquée, 42(I), 87 - II 4 .

Fairris, D., Jonasson, E. (2008): What accounts for intra-industry wage differentials? Results from a survey of establishment, in: Journal of Economic Issues, 52(I), 97 - II4.

Febrero, E. (2008): The monetization of profits in a monetary circuit framework, in: Review of Political Economy, 2O(I), III - I25.

Fontana, G., Realfonzo, R. (eds.) (2005): The Monetary Theory of Production, New York: Palgrave Macmillan.

Forges Davanzati, G. (2007): A Veblenian monetary theory of production, consumption and waste, URL: http://www.boeckler.de/pdf/v_2007_IO_26_davanzati-realfonzoI.pdf.

Forges Davanzati, G., Realfonzo, R. (2009): Money, capital turnover, and the leisure class: Thorstein Veblen's tips for a monetary theory of production, in: Ponsot, J.F., Rossi, S. (eds.), The Political Economy of Monetary Circuits: Tradition and Change, Basingstoke: Palgrave, forthcoming.

Graziani, A. (2003): The Monetary Theory of Production, Cambridge: Cambridge University Press.

Hayakawa, H. (1999): Bounded rationality, social and cultural norms, and interdependence via reference groups, in: Journal of Economic Behaviour and Organization, 43, I- 34 .

Hayakawa, H., Venieris, Y.P. (1977): Consumer interdependence via reference groups, in: Journal of Political Economy, 85, 599 - 6i5.

Hein., E. (2008): Money, Distribution Conflict and Capital Accumulation. Contributions to $M o n-$ etary Analysis‘, Basingstoke: Palgrave Macmillan.

Hein, E., Truger, A. (2007): Monetary policy, macroeconomic policy mix and economic performance in the Euro area, in: Hein, E., Truger, A. (eds.), Money, Distribution and Economic Policy, Cheltenham: Elgar, 216 - 244.

Jappelli, T., Pagano, M. (1989): Consumption and capital market imperfections: An international comparison, in: American Economic Review, 79(5), I088 - IIo5.

Jappelli, T., Pagano, M. (1994): Saving, growth and liquidity constraints, in: Quarterly Journal of Economics, IO9(I), 83 - I09.

Keynes, J.M. (1971 [1930]), A Treatise on Money. The Pure Theory of Money, Cambridge: Cambridge University Press.

Keynes, J.M. (1936): The General Theory of Employment, Interest and Money, London: Macmillan.

Kiff, J., Mills, P. (2007): Money for nothing and checks for free: Recent developments in U.S. subprime mortgage markets, International Monetary Fund Working Paper, No. 07/188.

Lavoie, M. (1992): Foundations of Post Keynesian Economics, Alderhot: Elgar.

Lawrence, E.C. (2008): A comparative analysis of payday loan customers, in: Contemporary Economic Policy, 26(2), 299-316.

Lee Mathews, H.L., Slocum, J.W. Jr. (1969): Social class and commercial bank credit card usage, in: Journal of Marketing, 33, 7I - 78 .

Lown, J.M. (2005): Educating and empowering consumers to avoid bankruptcy, in: International Journal of Consumer Studies, 20(5), 4OI - 408. 
Ludvigson, S. (1999): Consumption and credit: A model of time-varying liquidity constraints, in: The Review of Economics and Statistics, 8I(3), 434- 447.

Maki, D.M. (2000): The growth of consumer credit and the household debt service burden, The Federal Reserve Board - Finance and Economics discussion series.

Messinis, G., Henry, O., Olekalns, N. (2002): Rational habit modification in consumption, in: Economic Modelling, 19, 665-678.

Messori, M., Zazzaro, A. (2005): Single-period analiysis: Financial markets, firms' failure and closure of the monetary circuit, in: Fontana, G., Realfonzo, R. (eds.), The Monetary Theory of Production, Basingstoke: Palgrave Macmillan, III - I23.

Nell, E. (2002): On realizing profits in money, in: Review of Political Economy, I4(4), 519 530.

Pacella, A. (2008): The effects of labour market flexibility in the monetary theory of production, in: Metroeconomica, 59(4), 608-632.

Palley, T.I. (2007): Financialization: What it is and why it matters, The Levy Economics Institute Working Paper, No. 525.

Parguez, A. (1980): Profit, épargne, investissement: Éléments pour une théorie monétaire du profit, in: Economie Appliquée, 43(2), 425 - 455.

Parguez, A. (2004): The solution of the paradox of profits, in: Arena, R., Salvadori, N. (eds.), Money, Credit and theRrole of the State, Aldershot: Ashgate, 257 - 270.

Parguez, A. (2007): Money creation, employment and economic stability: The monetary theory of unemployment and inflation or why there cannot be a trade-off between employment and inflation: targeting true employment is the golden path to genuine true stability, Paper presented at the Third International Post-Keynesian Conference of Dijon in November.

Pivetti, M. (1991): An essay onMoney and Distribution, New York: St. Martin's Press.

Power, D., Epstein, G., Abrena, M. (2003): Trends in the rentier income share in OECD countries, I960-2000, PERI Working Paper, No. 58.

Ramaswamy, R., Rowthorn, R. (1991): Efficiency wages and wage dispersion, DAE Working Paper, No. 90I2.

Realfonzo, R. (2003): Circuit theory, in: Elgar, E., King, J.K. (eds.), The Elgar Companion to Post Keynesian Economics, Cheltenham: Edward Elgar, $60-65$.

Renaud, J.F. (2000): The problem of the monetary realization of profits in a Post Keynesian sequential financial model: Two solutions of the Kaleckian option, in: Review of Political Economy, I2(3), 285-303.

Robinson, J. (1962): Essays in the Theory of Economic Growth, London: Macmillan.

Rochon, L.P. (2005): The existence of monetary profits within the monetary circuit, in: Fontana, G., Realfonzo, R. (eds.), The Monetary Theory of Production, Basingstoke: Palgrave Macmillan, I25- I38.

Rossi, S. (2002): Money and Inflation, Aldershot: Edward Elgar.

Rowthorn, R. (1977): Conflict, inflation and money, in: Cambridge Journal of Economics, I, 215 -239 . 
Schmid, A.A. (2004): Conflict and Cooperation. Institutional and Behavioural Economics, Oxford: Blackwell.

Seccareccia, M. (2003): Pricing, investment and the financial of production within the framework of the monetary circuit: Some preliminary evidence, in: Rochon, L.P., Rossi, S. (eds.), Modern Theories of Money. The Nature and Role of Money in Capitalistic Economies, Cheltenham: Edward Elgar, I73 - I97.

Seccareccia, M. (2005): Growing household indebtness and the plummeting saving rate in Canada: An explanatory note, in: The Economic and Labour Relations Review, I6(I), I33 - I5I.

Setterfield, M. (2007): The rise, decline and the rise of incomes policies in the US during the post-war era: An institutional-analytical explanation of inflation and the functional distribution of income, in: Journal of Institutional Economics, 2, I27 - I46.

Slocum, J.W. Jr., Lee Mathews, H. (1970): Social class and income as indicators of consumer credit behavior, in: Journal of Marketing, 34, 69-74.

Soman, D., Cheema, A. (2002): The effect of credit on spending decisions: The role of the credit limit and credibility, in: Marketing Science, 2I(I), $32-53$.

Steindl, J. (1952): Maturity and Stagnation in American Capitalism, Oxford: Basil Blackwell.

Sullivan, T.A., Thorne, D., Warren, E. (200I): Young, old, and in between: Who files for bankruptcy?, in: Norton Bankruptcy Law Advisor, 9, I - Io.

Sullivan, T.A., Warren, E., Westbrook, J.L. (2000): The Fragile Middle Class: Americans in Debt, New Haven, CT: Yale University Press.

Sylos Labini, P. (I97I): La théorie des prix en régime d'oligopole et la théorie du développement, in: Revue d'Economie Politique, 8I(2), 244-272.

Tagkalakis, A. (2007): The effects of fiscal policy on consumption in recessions and expansions, in: Journal of Public Economics, 92, I486 - I508.

Wiles, P. (1973): Cost inflation and the state of economic theory, in: Economic Journal, 83, 377 $-398$.

Zazzaro, A. (2003): How heterodox is the heterodoxy of monetary circuit theory? The nature of money and the microeconomics of the circuit, in: Rochon, L.P., Rossi, S. (eds.), Modern Theories of Money, The Nature and Role of Money in Capitalist Economies, Cheltenham: Edward Elgar, 219-245.

Zezza, G. (2004): Some simple, consistent model of the monetary circuit, The Levy Economics Institute Working Paper, No. 405.

Zezza, G. (2008): The U.S. Housing Market: A Stock-Flow Consistent Approach, Paper presented at the author's seminar in Paris XIII, February 2008. 
